\title{
Influência do peso ao nascimento e lesões no desempenho de leitões lactentes*
}

\author{
CRISTIANE DA SILVA DUARTE FURTADO \\ Fernando Pandolfo Bortolozzo (Orientador - UFRGS) \\ Ivo Wentz (Co-orientador - UFRGS) \\ Mari Lourdes Bernardi (Co-orientadora - UFRGS)
}

Banca: Antônio Mario Penz Jr. (UFRGS), Guilherme Borchardt Neto (UNICRUZ), Rui Fernando Félix Lopes (UFRGS)

O peso dos leitões ao desmame está possivelmente relacionado ao desempenho posterior e sofre influência de diversos fatores relacionados ao ambiente, à matriz e aos próprios leitões. O peso ao nascimento, a presença de lesões orais, dentárias, umbilicais e no aparelho locomotor podem comprometer o ganho de peso dos leitões na maternidade. Foram acompanhados 2004 lactentes, os quais foram pesados e avaliados para a presença de lesões no primeiro dia e aos 7, 14 e 21 (desmame) dias de vida. Leitões nascidos com peso entre $600 \mathrm{~g}$ e $900 \mathrm{~g}$ tiveram mortalidade até o desmame superior àqueles pesando entre $901 \mathrm{~g}$ e $1200 \mathrm{~g}(\mathrm{P}<0,05)$. Entre os leitões nascidos com peso acima de $1500 \mathrm{~g}$ não houve diferença na mortalidade $(\mathrm{P}>0,05)$. O peso ao nascimento apresentou correlação positiva com o peso ao desmame $(\mathrm{P}<0,05)$. A ocorrência de lesões orais, umbilicais ou dentárias não comprometeu o desempenho. Por outro lado, a presença de lesões no aparelho locomotor afetou negativamente o peso ao desmame $(\mathrm{P}<0,05)$. Leitões com lesões no aparelho locomotor na segunda semana de vida apresentaram peso inferior àqueles com lesões na primeira semana $(\mathrm{P}<0,05)$. Leitões leves $(=600 \mathrm{~g}-<1300 \mathrm{~g})$ com lesões no aparelho locomotor não sofreram redução do peso ao desmame (P>0,05), enquanto os leitões médios (=1300g- $<1800 \mathrm{~g})$ e pesados $(=1800 \mathrm{~g})$ com lesões tiveram peso inferior ao daqueles sem lesões $(\mathrm{P}<0,05)$. O peso ao nascimento e a ocorrência de lesões no aparelho locomotor podem comprometer a performance dos leitões lactentes.

Descritores: Leitões, lesões, peso ao desmame, desempenho.

Apresentada: 26 fevereiro 2007

*Dissertação de Mestrado n 458 (Especialidade: Fisiopatologia da Reprodução). 45f. Programa de Pós-Graduação em Ciências Veterinárias [www.ufrgs.br/ppgcv], Faculdade de Veterinária, Universidade Federal do Rio Grande do Sul (UFRGS), Porto Alegre, RS. CORRESPONDÊNCIA: Fernando P. Bortolozzo [fpbortol@ufrgs.br]. 


\title{
Influence of birth weight and lesions on performance of suckling piglets**
}

\author{
CRISTIANE DA SILVA DUARTE FURTADO
}

\author{
Fernando Pandolfo Bortolozzo (Adviser - UFRGS) \\ Ivo Wentz (Co-adviser - UFRGS) \\ Mari Lourdes Bernardi (Co-adviser - UFRGS)
}

Committee: Antônio Mario Penz Jr. (UFRGS), Guilherme Borchardt Neto (UNICRUZ), Rui Fernando Félix Lopes (UFRGS)

Weaning weight of piglets is positively related with performance in later ages and is influenced by several factors connected with environment, the sow and the piglets. The birth weight, presence of oral, dental, umbilical or limb lesions can compromise the performance of suckling piglet. A total of 2004 suckling piglets were weighed and evaluated for the presence of lesions in the first day of life and on 7, 14 and 21 days. Pigs with birth weight between $600 \mathrm{~g}$ and $900 \mathrm{~g}$ presented preweaning mortality higher than those with weight between $901 \mathrm{~g}$ and $1200 \mathrm{~g}(\mathrm{P}<0.05)$. Among piglets with birth weight above $1500 \mathrm{~g}$, there was no difference in mortality $(\mathrm{P}>0.05)$. Birth weight presented a positive correlation with weaning weight $(\mathrm{P}<0.05)$. Occurrence of oral, umbilical or dental lesions did not compromise performance. On the other hand, the presence of limb lesions affected negatively the weaning weight $(\mathrm{P}<0.05)$. Piglets with limb lesions in the second week of life presented smaller weight when compared with those with lesions only in the first week of life $(\mathrm{P}<0.05)$. Lighter piglets $(=600 \mathrm{~g}-<1300 \mathrm{~g})$ with limb lesions did not show reduction in weaning weight $(\mathrm{P}>0.05)$ while those with intermediate weight $(=1300 \mathrm{~g}-<1800 \mathrm{~g})$ and heavier $(=1800 \mathrm{~g})$, with lesions, had smaller weight when compared to those without lesions $(\mathrm{P}<0.05)$. It is concluded that birth weight and the occurrence of limb lesions can compromise the performance of suckling piglets.

Key words: Piglets, lesions, weaning weight, performance.

\footnotetext{
**Master's Thesis \#458 (Field: Theriogenology). 45p. Graduated Program in Veterinary Sciences [www.ufrgs.br/ppgcv], Faculdade de Veterinária, Universidade Federal do Rio Grande do Sul (UFRGS), Porto Alegre/Brazil. CORRESPONDENCE: Fernando P. Bortolozzo [fpbortol@ufrgs.br].
} 